\title{
PENINGKATAN MUTU PRESTASI BELAJAR AGAMA HINDU MELALUI MODELPEMBELAJARAN KOOPERATIF DI SMPN 2 MALANG
}

\author{
Oleh \\ Made Dwianan Mustawan \\ Dosen STAH Santika Darma
}

\begin{abstract}
ABSTRAK
Pembelajaran agama Hindu di SMPN2 Malang dipilihlah metode atau model pembelajaran kooperatif untuk peningkatan mutu prestasi belajar agama Hindu. Belajar kooperatif dapat mengembangkan tingkah laku kooperatif dan hubungan yang lebih baik antar siswa. Dalam belajar kooperatif siswa belajar lebih banyak dari temannya mereka dari pada gurunya. Kemudian dalan interkasi dengan pembelajaran kooperatif dapat memacu terbentuknya ide-ide baru dan memperkaya perkembangan intlektual siswa. Belajar kooperatif sangat efektif untuk memperbaiki hubungan antarsuku dan etnis dalam kelas mutibudaya, mengingat siswa yang ada di SMPN 2 Malang lebih dominan adalah beragama muslim. Jadi dengan model kooperatif pembelajaran agama dalam meningkatkan mutu prestasi belajar agama sangat efektif dilakukan oleh guru agama Hindu.

Pembelajaran kooperatif mempunyai efek yang berarti terhadap penerimaan yang luas terhdap keragaman ras, budaya, dan agama, strata sosial, kemampuan dan ketidak mampuan. Peningkatan mutu prestasi belajar agama Hindu dengan model kooperatif memberikan peluang kepada siswa yang berada latar belakang dan kondisi untuk bekerja saling bergantung satu sama lain atas tugas-tugas bersama, dan melalui penggunaan struktur penghargaan kooperatif, belajar untuk menghargai satu sama lain.
\end{abstract}

Kata Kunci: Peningkatan mutu prestasi belajar agama Hindu.

\section{ABSTRACT}

Learning of Hinduism in SMPN2 Malang was chosen method or model of cooperative learning to improve the quality of learning achievement of Hindu religion. Cooperative learning can develop cooperative behavior and better relationships among students. In cooperative learning, students learn more from their friends than their teachers. Then in interaction with cooperative learning can spur the formation of new ideas and enrich the students' intellectual development. Cooperative learning is very effective for improving tribal and ethnic relationships in mutuality classes, considering that students in SMPN 2 Malang are more dominant are Muslims. So with the cooperative model of religious learning in improving the quality of religious learning achievement is very effective done by teachers of Hindu religion.

Cooperative learning has a significant effect on the widespread acceptance of racial, cultural, and religious diversity, social strata, abilities and disabilities. Improving the quality of Hindu learning achievements with cooperative models provides opportunities for students who are in the background and conditions to work interdependent on one another over shared tasks, and through the use of cooperative rewards structures, learn to respect each other.

Keywords: Increasing the quality of learning achievement of Hinduism.

Peningkatan Mutu Prestasi Belajar Agama Hindu

Melalui Modelpembelajaran Kooperatif di SMP N 2 Malang 


\section{PENDAHULUAN}

Guru adalah pendidik profesional dengan tugas utama mendidik, mengajar, membimbing, mengarahkan, melatih, menilai, dan mengevaluasi peserta didik pada pendidikan anak usia dini jalur pendidikan formal, pendidikan dasar, dan pendidikan menengah PP. No. 74 tahun 2008 (pasal 1) tentang guru. Sebagai seorang guru yang mengajar di tingkat dasar mesti memahami terlebih dahulu tingkat perkembangan anak. Anak-anak yang duduk di SMP adalah tergolong anak-anak yang akan mengalai masa peralihan dari masa kecil menuju masa remaja. Agar guru mampu melaksanakan pembelajaran dengan baik maka guru harus giat melakukan kegiatan bermain sambil belajar. Dalam mengajar, guru harus giat melakukan model-model yang dapat membantu anakanak agar kebutuhan mereka terpenuhi.

Pengembangan kurikulum di tingak dasar dalam (Depdiknas: 2009) dikembangkan berdasarkan prinsip-prinsip sebagai berikut: (1) berpusat pada potensi, perkembangan, kebutuhan, dan kepentingan peserta didik dan lingkungannya; (2) beragam dan terpadu; (3) tanggap terhadap perkembangan ilmu pengetahuan, teknologi dan seni; (4) relevan dengan kebutuhan kehidupan; (5) menyeluruh dan berkesinambungan; (6) belajar sepanjang hayat; dan (7) seimbang antara kepentingan nasional dan kepentingan daerah.

Sekolah menengah tingkat pertama (SMP) yang tergolong pendidikan dasar dalam program pemerintah sebagai pendidikan dasar sembilan tahun dalam meningkatkan prestasi belajar dan mutu pendidikan di Indonesia serta meningkatkan kecerdasan anak bangsa. Untuk itulah pembaharuan dari segi kurikulum pendidikan selalu dilakukan demi meluruskan dan memuluskan jalan bagi peserta didik untuk menemukan jati diri mereka, memperoleh bekal pengetahuan hidup yang relevan untuk dimanfaatkan menghadapi arus globalisasi yang ditandai dengan pesatnya perkembangan terknologi informasi.

Dengan demikian pembelajaran yang bernuansa kooperatif harus dirancang sedemikian rupa sehingga mampu merangsang siswa untuk berfikir dan mendorong menggunakan pikirannya secara sadar untuk memecahkan masalah. Belajar kooperatif pada hakekatnya adalah belajar bersama dalam mengaplikasikan pengetahuan-pengetahuan yang telah diperoleh sebelumnya untuk memecahkan masalah-masalah baru yang sudah dijumpai pada kehidupan keagamaan di lingkungan masing-masing.

Sehubungan dengan hal itu, guru agama Hindu di SMPN 2 Malang dituntut sangat giat dalam mengembangkan pengetahuan dan pemahama agama Hindu dalam proses pembelajaran, mengingat peserta didik yang beragama Hindu belajar di SMPN 2 Malang masih merupakan kertas putih yang belum berisi banyak tulisan. Untuk itu sebagai pendidik harus mampu melaksanakan proses pembelajaran dengan baik agar mampu meningkatkan mutu pendidikan bagi peserta didik.

Tugas seorang guru tidaklah ringan. Karena dalam mendidik anak tidak seperti mengisi ember kosong. Menurut H.D. Iriyanto (2012: 44) bahwa pendidikan bukanlah seperti mengisi ember kosong, tetapi seperti menyalakan api yang hampir padam. Kesuksesan karier itu lebih bergantung pada kemampuan seseorang memahami diri sendiri, kemampuan mengelola diri sendiri secara efektif, kemampuan untuk memahami orang lain dan kemampuan untuk mengelola hubungan dengan orang lain. Juga disampaikan bahwa tugas seorang guru yang sesungguhnya bukanlah menyiapkan para siswa agar nilainya bagus dan lulus ujian tetapi menyiapkan mereka agar menguasai ilmu pengetahuan, keterampilan dan kematangan pribadi yang dibutuhkan untuk meraih 
keselamatan dan kebahagiaan hidup, baik di dunia maupun akhirat, selama mereka berada di lingkungan sekolah. Selain pemahaman tentang dunia pendidikan, seorang guru juga harus memahami karakteristik peserta didiknya. Karena hal itu, akan lebih memudahkan guru untuk mengarahkan dan memberikan bimbingan yang benar demi peningkatan pengembangan kemampuan dan prestasi peserta didik.

Dengan memahami semua cuplikan di atas seharusnya proses pembelajaran akan dapat berjalan dengan baik dan prestasi belajar siswa juga akan mencapai hasil yang baik. Namun kenyataan yang ada di SMP N2 Malang Jawa Timur proses pembelajarannya belum optimal untuk mencapai nilai diatas 7,5 mengingat serba kerterbatasannya baik itu saran dan prasarana dan juga jumlah siswanya sangat minim yaitu untuk kelas VII jumlah keseluruhan 33 siswa, kelas VIII jumlahnya 30 siswa, dan kelas IX jumlah siswanya 32 siswa. Tenaga pendidik berstatus honor, waktu jam belajarnya tergantung pada guru yang bersangkutan. Dari analisa yang dilakukan didapat bahwa penyebab rendahnya nilai anak-anak tersebut adalah: (1) keterbatasan siswa dalam menerima pelajaran guru; (2) Keterbatasan dalam penerapan strategi pembelajaran oleh guru agama; (3) keterbatasan sarana dan prasarana; (4) keterbatasan pemahaman guru terhadap substansi materi yang akan di ajarkan; (5) keterbatasan guru dalam menerapkan model model pembelajaran alternatif.

Sehubungan dengan hal tersebut maka guru harus mengupayakan cara untuk bisa mengatasinya. Untuk itu dipilihlah metode atau model pembelajaran kooperatif untuk peningkatan mutu prestasi belajar agama Hindu. Menurut Ibrahim (dalam Trianto, 2014:113) mengatakan bahwa belajar kooperatif dapat mengembangkan tingkah laku kooperatif dan hubungan yang lebih baik antar siswa. Dalam belajar kooperatif siswa belajar lebih banyak dari temannya mereka dari pada gurunya. Kemudian dalan interkasi dengan pembelajaran kooperatif dapat memacu terbentuknya ide-ide baru dan memperkaya perkembangan intlektual siswa. Belajar kooperatif sangat efektif untuk memperbaiki hubungan antarsuku dan etnis dalam kelas mutibudaya, mengingat siswa yang ada di SMPN 2 Malang lebih dominan adalah beragama muslim. Jadi dengan model kooperatif pembelajaran agama dalam meningkatkan mutu prestasi belajar agama sangat efektif dilakukan oleh guru agama Hindu.

\section{PEMBAHASAN}

Belajar kompetitif dan induvidualistik akan efektif dan merupakan cara memotivasi siswa untuk melalukan yang terbaik. Meskipun demikian, terdapat beberapa kelemahan pada belajar kompetitif dan induvidualistik yaitu: (a) kompetisi siswa kadang tidak sehat. Sebagai contoh, jika seorang siswa menjawab pertanaan guru, siswa yang lain berharap agar jawaban yang diberikan salah; (2) siswa yang berkemampuan rendah akan kurang termotivasi, dan sulit akan sukses serta semakin tertingal. Untukm mengindaran halhal tersebut dan agar siswa dapat membanu siswa yang alain untuk mencapai sukses, maka jalan keluarnya yakni dengan belajar kooperatif.

Belajar kooperatif bukanlah suatu hal yang baru. Sebagai guru dan mungkin siswa kita pernah menggunakannya atau mengalaminya, sebagai contoh saat bekerja di laboratorium. Dalam belajar kooperatif, siswa dibentuk dalam kelompok-kelompok yang terdiri dari empat atu lima orang untuk bekerja sama dalam menguasai materi yang diberikan guru Newman (dalam Trianto, 2014:108). Dalam belajar kooperatif siswa Hindu SMPN 2 Malang belajar bersama sebagai suatu tim dalam menyelesaikan tugas kelompok yang diberikan oleh guru untuk mencapai tujuan

Peningkatan Mutu Prestasi Belajar Agama Hindu

Melalui Modelpembelajaran Kooperatif di SMP N 2 Malang 
bersama. Jadi setiap anggota kelompok memiliki tanggung jawab yang sama untuk mewakili kelompoknya.

Pembelajaran kooperatif bernaung dalam teori konstruktivis. Pembelajaran ini muncul dari konsep bahwa siswa akan lebih mudah menemukan dan memahami konsep yang sulit jika mereka saling berdiskusi dengan temannya. Siswa secara rutin bekerja dalam kelompok untuk saling membantu memecahkan masalah yang kompleks. Jadi hakekat sosial dan penggunaan kelompok sejawat menjadi aspek utama dalam pembelajaran kooperatif.

Di dalam kelas kooperatif siswa SMPN 2 Malang belajar bersama dalam kelompok kecil yang terdiri dari 4-6 orang siswa yang sederajat tetapi heterogen, kemampuan, jenis kelamin, suku/ras, dan satu sama lain saling membantu. Tujuan dibentuknya kelompok ini yakni untuk memberikan kesempatan kepada semua siswa untuk dapat terlibat secara aktif dalam proses berpikir dan kegiatan belajar. Selama bekerja dalam kelompok tugas anggota kelompok yaitu mencapai ketuntasan belajar.

Selama belajar secara kooperatif siswa SMPN 2 Malang tetap tinggal dalam kelompok selama beberapa kali pertemuan. Mereka diajarkan keterampilan khusus agar dapat bekerja sama dengan baik di dalam kelompoknya, seprti menjadi pendengan aktif, memberikan penjelasan kepada teman kelompok dengan baik, dan berdiskusi. Agar terlaksana dengan baik, siswa diberi lembar kegiatan yang berisi pertanyaan atau tugas yang direncanakan untuk diajarkan. Selama bekerja dalam anggota kelopok adalah mencapai ketuntasan materi yang disajikan guru dan saling membantu di antara teman sekelompok untuk mencapai ketuntasan materi. Belajar belum selesai jika salah satu anggota kelompok ada yang belum menguasai materi pelajaran. Sebagaimana model-model pembelajaran kooperatif memiliki tujuan, langkah-langkah, dan lingkungan belajar dan system pengelolaan yang khas seperti:

\section{Tujuan Pembelajaran Kooperatif}

Ide utama belajar kooperatif yaitu bahwa siswa bekerja sama untuk belajar dan bertanggung jawab pada kemajuan belajar temannya. Sebagaitambahanbelajarkooperatif menekankan pada tujuan dan kesuksesan kelompok yang hanya dapat dicapai jika semua anggota kelompok mencapai tujuan atau penguasaan materi. Salvin (dalam Trianto, 2014:109) menyatakan bahwa tujuan pokok belajar kooperatif ialah memaksimalkan belajar siswa untuk meningkatkan prestasi akademik dan pemahaman, baik secara individu maupun secara kelompok. Karena siswa bekerja dalam satu tim, maka dengan sendirinya dapat memperbaiki hubungan diantara siswa dari berbagai latar belakang etnis dan kemampuan, mengembangkan ketrampilan proses kelompok dan pemecahan masalah. Zamboni (dalam Trianto, 2014:109) mengemukakan bahwa mafaat penerapan belajar kooperatif yakni dapat mengurangi kesenjangan pendidikan khususnya dalam wujud input pada level individual. Disamping itu belajar kooperataif dapat mengembangkan solidaritas sosial di kalangan siswa. Dengan belajar kooperatif, diharapkan kelak akan muncul generasi baru yang memiliki prestasi akdemik yang cemerlang dan memiliki solidaritas sosial yang kuat.

Pembelajaran kooperatif merupakan suatu kelompok strategi pengajaran yang melibatkan siswa bekerja secara berkolaborasi untuk mencapai tujuan bersama. Pembelajaran kooperatif disusun daalm suatu usaha untuk meningkatkan partisipasi siswa., memfasilitasi siswa dengan pengalaman sikap kepemimpinan dan membuat keputusan dalam kelompok, serta memberikan kesempatan pada siswa untuk berinteraksi dan belajar bersama-sama siswa yang berbeda latar belakangnya. Jadi dalam pembelajaran 
kooperatif siswa berperan ganda, yaitu sebagai siswa ataupun guru. Dengan bekerja sama secara kolaboratif untuk mencapai tujuan bersama, maka siswa akan mengembangkan ketrampilan berhubungan dengansesama manusia yang akan sangat bermanfaat bagi kehidupan diluar sekolah.

Struktur tujuan kooperatif terjadi jika siswa dapat mencapai tujuan mereka, hanya jika siswa lain dengan siapa mereka bekerja samamencapai tujua itu. Tujuan pembelajaran ini mencakup tuga jenis tujuan penting, yaitu hasil belajar akademik, penerimaan terhadap keragaman,dan mengembangkanketrampilan sosial. (Ibrahim, dkk 2000:7).

Para ahli telah menunjukkan bahwa pembelajaran kooperatif dapat meningkatkan kinerja siswa dalam tugas-tugas akademik, unggul dalam membantu siswa memahmi konsep yang sulit, dan membantu siswa menumbukha kemampuan berpikir kritis. Pembelajaran kooperatif dapat memberikan keuntungan, baik pada siswa kelompok bawah maupun kelompok atas yang bekerja bersama menyelesaikan tugas-tugas akademik.

Pembelajaran kooperatif di SMPN 2 Malang mempunyai efek yang sangat berarti terhadap penerimaan yang luas baik keragaman ras, budaya, dan agama, sehingga siswa-siswi yang ada di SMPN 2 Malang baik Hindu, Islam, Kristen katolik sangat rukun dan damai, karena pada prinsipnya mereka kita adalah satu bangsa dan satu bahasa. Pembelajaran kooperatif memberikan peluang kepada siswa yang berada latar belakang dan kondisi untuk bekerja saling bergantung satu sama lain atas tugas-tugas bersama, dan melalui penggunaan struktur penghargaan kooperatif, belajar untuk menghargai satu sama lain.

Ketrampilan sosial atau kooperatif berkembang secara signifikan dalam pemeblajaran kooperatif. Pembelajaran kooperatif sangat tepat digunakan untuk melatihkan ketrampilan kerja sama dan kalborasi, dan juga ketrampilan Tanya jawab.

\section{Unsur Penting dan Prinsip Utama Pembelajaran Kooperatif}

Sebagai wujud ketrampilan dalam belajar kooperatif terdapat lima unsur penting dalam belajar kooperatif, yaitu pertama, saling ketergantungan yang bersifat positif antara siswa. Dalam belajar kooperatif siswa merasa bahwa mereka sedang bekerja sama untuk mencapai tujuan dan terikat satu sama lain. Seorang siswa tidak akan sukses kecuali semua anggota kelompoknya juga sukses. Siswa akan merasa bahwa dirinya merupakan bagian dari kelompok yang juga mempunyai andil terhadap suksenya kelompok.

Kedua, interkasi siswa yang semakin meningkat. Belajar kooperatif akan meningkat interaksi antara siswa. Hal ini terjadi daalm hal seseorang siswa akan membantu siswa lain untuk sukses sebagai anggota kelompok. Saling memberikan bantuan ini akan berlangsung secara alamiah, karena kegagalan seseorang dalam kelompok akan mempengaruhi suksesnya kelompok. Untuk mengatasi masalah ini siswa siswa yang membutuhkan bantuan akan mendapatkan dari teman sekelompoknya. Interkasi yang terjadi dalam belajar kooperatif yakni dalam tukar menukar ide mengenai masalah yang sedang dipelajari bersama.

Ketiga, tanggung jawab individual. Tanggung jawab individual dalam belajar kelompok dapat berupa tanggung jawab siswa dalam hal; (a) membantu siswa yang membutuhkan bantuan; dan (b) siswa tidak dapat hanya sekedar "membonceng" pada hasil kerja teman sekelompoknya.

Keempat, ketrampilan interpersonal dan kelompok kecil. Dalam belajar kooperatif, selain dituntut untuk mempelajari materi yang diberikan seseroang siswa dituntut untuk belajar bagaimana berinterkasi dengan siswa lain dalam kelompknya. Bagaimana siswa bersikap sebagai anggota kelompok

Peningkatan Mutu Prestasi Belajar Agama Hindu

Melalui Modelpembelajaran Kooperatif di SMP N 2 Malang 
dan menyampaikan ide dalam kelompok akan menunut ketrampilan khusus.

Kelima, proses kelompok. Belajar kooperatif tidak akan berlangsung tanpa proses kelompok. Proses kelompok terjadi jika anggota kelompok berdiskusi bagaimana mereka akan mencapai tujuan dengan baik dan membuat hubungan kerja yang baik. Selain lima unsur penting yang terdapat dalam model pembelajaran kooperatif, model pembelajaran ini juga mengandung prinsip-prinsip yang membedakan dengan model pembelajaran lain. Konsep utama dari belajar kooperatif menurut Slavin (dalam Al-Tabany, 2014: 113 yaitu:

a. Penghargaan kelompok, yang akan diberikan jika kelompok mencapai kriteria yang ditentukan.

b. Tanggung jawab individual, bermakna bahwa suksesnya kelompok tergantung pada belajar individual semua anggota kelompok. Tanggung jawab ini terfokus dalam usaha untuk membantu yang lain dan memastikan setiap anggota kelompok telah siap menghadapi evaluasi tanpa bantuan yang lain.

c. Kesempatan yang sama untuk suskses, bermakan bahwa siswa telah membantu kelompok dengan cara meningkatkan belajar mereka sendiri. Hal ini memastikan bawa siswa berkemampuan tinggi, sedang, dan rendah sama-sama tergantung untuk melakukan yang terbaik dan bahwa kontribusi semua angota kelompok sangat bernilai.

\section{Implikasi Model Pembelajaran Kelompok}

Menurut Ibrahim (dalam AlTabany,Trianto, 2014:113) bahwa belajar kooperatif dapat membangun tingkah laku kooperatif dan hubungan yang lebih baik antar siswa, dan dapat mengembangkan kemampuan akademis siswa. Siswa belajar lebih banyak dari teman mereka dalam belajar kooperati dari pada dari guru.

Ratumanan (2002) menyatakan bahwa, intrkasi yang terjadi dalam belajar kooperatif dapat memacu terbentuknya ide barudan memperkaya perkembangan intelektual siswa. Menurut Kardi \& Nur (2000), belajar kooperatif sangat efektif untuk memperbaiki hubungan antar suku dan etnis dalam kelas multibudayadan memperbaiki hubungan antar siswa. Davidson (dalamTrianto, 2014: 113) memberikan sejumlah implikasi positif dalam pembelajaran dengan menggunakan strategi belajar kooperatif sebagai berikut.

a. Kelompok kecil memberikan dukungan sosial utnuk belajar. Kelompok kecil membantu suatu forum di mana siswa menanyakan pertanyaan, mendidkusikan pendapat, belajar dari pendapat orang lain, memberikan kritik yang membangun dan menyimpulkan penemuan mereka dalam bentuk tulisan.

b. Kelompok kecil menawarkan kesempatan untuk sukses bagi semua siswa. Interaksi dalam kelompok dirancang untuk semua anggota mempelajari konsep dan strategi pemecahan masalah.

c. Suatu masalah idealnya cocok untuk diskusikan secara kelompok, sebab memilki solusi yang dapat didemontrasikan secar objektif. Seorang siswa dapat memengaruhi siswa lain dengan argumentasi yang logis.

d. Siswa dalam kelompok dapat membantu siswa lain untuk menguasai masalahmasalah dasar dan prosedur perhitungan yang perlu dalam konteks permainan, teka-teki, atau pembahasan masalahmasalah yang bermanfaat.

e. Ruang lingkup materi dipenuhi oleh ide-ide menarik dan menantang yang bermanfaat bial diiskusikan.

Belajar koprati dapat berbeda dalam 
banyak cara, tetapi dapat dikatagorikan sesuai dengan sifat berikut: (1) tujuan kelompok, (2) tanggung jawab individual, (3) kesempatan yang sama untk sukses, (4) kompetisi kelompok. (5) spesialisasi tugas, dan (6) adaptasi untuk kebutuhan individu.

\section{Lingkungan Belajar dan Sistem Pengelolaan}

Pembelajaran kooperatif bertitik tolak dari pendapatnya Jhon Dewy (dalam Ibrahim, 2000) menyatakan pendidikan dalam masyarakat yang deokratis seyogyanya mengajarkan proses demokratis secara langsung. Tingkah laku kooperatif dipandang oleh Jhon Dewy dan Thelan sebagai dasar demokratis, dan sekolah dipandang sebagai laboratorium utuk mengembangkan tingkah laku demokratis.

Proses demokratis dan peran aktif merupakan cirri yang khas dari lingkungan pembelajaran kooperatif. Daalm pembentukan kelompok guru menerapkan struktur tingkat tinggi, dan guru juga mendefinisikan semua prosedur. Meskipun demikian, guru tidak dibenarkan mengelola tingkah laku siswa dalam kelompok secara ketat, dan siswa memilki ruang danpeluanguntuk secara bebasmengendalikan aktivitas di dalam kelompoknya. Selain itu pembelajaran koperatif menjadi sangat efektif jika materi pemeblajaran tersedia lengkap di kelas ruang guru, di perpustakaan, ataupun di pusat media.

Pembelajaran kooperatif daapt berjalan sesuai dengan harapan, dan siswa dapat bekerja secara produktif dalam kelompok, maka siswa perlu diajarkan ketrampilanketrampilan kooperatif. Ketrampilan kooperatif ini berfungsi untuk melancarkan peranan hubungan kerja dan tugas. Peranan hubungan kerja dapat dibangun dengan mengembangkan komunikasi antara anggota kelompok, sedangkan peranan tugas dapat dilakukan dengan membagi tugas antar anggota kelompok.

Unsur-unsur dasar yang perlu untuk ditanam kepada siswa agar pembelajaran kooperatif dapat berjalan lebih efektif lagi yaitu:

a. Para siswa harus memiliki persepsi sama bahwa mereka bersama-sama dalam suka duka.

b. Para siswa memiliki tanggung jawab terhadap tiap siswa lain dalam kelompoknya, di samping tanggung jawab terhadap dirinya sendiri, dalam mempelajari materi yang dihadapi.

c. Para siswa harus berpandangan bahwa mereka semuanya memiliki tujuan yang sama

d. Para siswa harus membagi tugas dan berbagai tanggung jawab sama berarnya di antara anggota kelompok.

e. Para siswa diberikan satu evaluasi atau penghargaan yang akan ikut berpengaruh terhadap evaluasi seluruh anggota kelompok.

f. Para siswa berbagai kepemimpinan, sementara mereka memperoleh ketrampilan bekerja sama selama belajar.

g. Para siswa diminta mempertanggungjawabkan secara individual materi yang ditangani dalam kelompok kooperatif.

\section{Langkah - langkah Pembelajaran Kooperatif}

Terdapat enam langkah utama atau tahapan di dalam pelajaran yang menggunakan pembelajaran kooperatif. Hal ini dapat dilihat dalam bentuk tabel. 
Tabel 1 Langkah-langkah model pembelajaran kooperatif

\begin{tabular}{|l|l|l|}
\hline No & \multicolumn{1}{|c|}{ Fase } & \multicolumn{1}{|c|}{ Tingkah Laku guru } \\
\hline 1 & $\begin{array}{l}\text { Fase 1: } \\
\text { Menyampaikan } \\
\text { tujuan dan } \\
\text { memotivasi siswa }\end{array}$ & $\begin{array}{l}\text { Guru menyampaikan } \\
\text { semua tujuan pelajaran } \\
\text { yang ingin dicapai } \\
\text { pada pelajaran tersebut } \\
\text { dan memotivasi siswa } \\
\text { belajar. }\end{array}$ \\
\hline 2 & $\begin{array}{l}\text { Fase 2: } \\
\text { Menyajikan } \\
\text { informasi }\end{array}$ & $\begin{array}{l}\text { Guru menyajikan } \\
\text { informasi kepada } \\
\text { siswa dengan jalan } \\
\text { demontrasi atau lewat } \\
\text { bahan bacaan. }\end{array}$ \\
\hline 3 & $\begin{array}{l}\text { Fase 3: } \\
\text { Mengorganisasikan } \\
\text { siswa ke dalam } \\
\text { kelompok kooperatif }\end{array}$ & $\begin{array}{l}\text { Guru menjelaskan } \\
\text { kepada siswa } \\
\text { bagaimana caranya } \\
\text { membentuk kelompok } \\
\text { belaajr dan membantu } \\
\text { setiap kelompok agar } \\
\text { melakukan transisi } \\
\text { secara efisien. }\end{array}$ \\
\hline 4 & $\begin{array}{l}\text { Fase 4: } \\
\text { Membimbing } \\
\text { kelompok bekerja } \\
\text { dan belajar }\end{array}$ & $\begin{array}{l}\text { Guru membimbing } \\
\text { kelompok-kelompok } \\
\text { belajar pada saat } \\
\text { mereka mengerjakan } \\
\text { tugas mereka. }\end{array}$ \\
\hline 5 & $\begin{array}{l}\text { Guru mengevaluasi } \\
\text { hasil belajar tentang } \\
\text { materi yamg telah } \\
\text { dipelajari atau masig- } \\
\text { masingg kelompok } \\
\text { mempersembahkan } \\
\text { hasil kerjanya. }\end{array}$ \\
Evaluasi & $\begin{array}{l}\text { Guru mencari cara } \\
\text { untuk menghargai baik } \\
\text { upaya maupun hasil } \\
\text { belajar individu dan } \\
\text { kelompok. }\end{array}$ \\
\hline Penghargaan & \\
\hline
\end{tabular}

\section{Beberapa Variasi dalam Model Cooperatif Learning}

Walaupun prinsip dasar pembelajaran kooperatif tidak berubah, terdapat beberapa variasi dan model tersebut. Sedikitnya terdapat empat pendekaatn yang seharusnya merupakan bagian dari kumpulan strategi guru dalam menerapkan model pembelajaran kooperatif yaitu; STAD, Jigsaw, investigasi kelompok, dan pendekatan struktural yang melipiuti numbered head together (NHT).

a. Studen Teams Achievement Division (STAD)

Pembelajaran kooperati tipe STAD ini merupakan salah satu dari tepe model pembelajaran kooperatif dengan menggunakan kelompok kecil dengan jumlah anggota tiap kelompok 4-5 orang siswa secara heterogin. Diawali dengan penyampaian tujuan pembelajaran, penyampaian materi, kegiatan kelompok, kuis, dan penghargaan kelompok.

b. Tim Ahli (Jigsaw).

Dalam belajar kooperatif tipe Jigsaw, secara umum siswa dikelompokkan secara heterogen dalam kemampuan. Siswa diberi materi yang baru atau pendalaman materi sebelunya untuk dipelajari. Masing-masing anggota kelompok secara acak ditugaskan untuk menjadi ahli pada suatu aspek tertentu dari materi tersebut.

c. Investigasi Kelompok (Group Investigation).

Investigasi kelompok merupakan model pembelajaran kooperatif yang paling kompleks dan paling sulit untuk diterapkan. Model ini di kembangkan pertama kali oleh Thelan. Dalam perkembangnya model ini diperluas dan dipertajam oleh Sharan. Pendekatan ini memerlukan norma dan struktur kelas lebih rumit dari pada pendekatan yang lebih berpusat pada guru. Pendekatan ini juga memerlukan mengajar siswa ketrampilan komunikasi dan proses kelompok yang baik.

d. Numbered Head Together (NHT)

Numbered Head Together (NHT) atau penomoran berpikir bersama merupakan jenis pembelajaran kooperatif yang dirancang untuk mempengaruhi pola interkasi siswa dan sebagai alternative 
terhadap strutur kelas yradisional. Numbered Head Together (NHT) pertamakali dikembangkan oleh Spenser Kagen (1993) untuk melibatkan lebih banyak siswa dalam menelaah materi yang tercakup dalam pelajaran dan menegcek pemahaman mereka terhadap isi pelajaran tersebut.

\section{SIMPULAN}

Belajar kooperatif bukanlah suatu hal yang baru. Sebagai guru dan mungkin siswa kita pernah menggunakannya atau mengalaminya, sebagai contoh saat bekerja di laboratorium. Dalam belajar kooperatif, siswa dibentuk dalam kelompok-kelompok yang terdiri dari empat atu lima orang untuk bekerja sama dalam menguasai materi yang diberikan guru.

Pembelajaran kooperatif bernaung dalam teori konstruktivis. Pembelajaran ini muncul dari konsep bahwa siswa akan lebih mudah menemukan dan memahami konsep yang sulit jika mereka saling berdiskusi dengan temannya. Siswa secara rutin bekerja dalam kelompok untuk saling membantu memecahkan masalah yang kompleks. Jadi hakekat sosial dan penggunaan kelompok sejawat menjadi aspek utama dalam pembelajaran kooperatif.

Di dalam kelas kooperatif siswa SMPN 2 Malang belajar bersama dalam kelompok kecil yang terdiri dari $4-6$ orang siswa yang sederajat tetapi heterogen, kemampuan, jenis kelamin, suku/ras, dan satu sama lain saling membantu. Tujuan dibentuknya kelompok ini yakni untuk memberikan kesempatan kepada semua siswa untuk dapat terlibat secara aktif dalam proses berpikir dan kegiatan belajar. Selama bekerja dalam kelompok tugas anggota kelompok yaitu mencapai ketuntasan belajar.

Selama belajar secara kooperatif siswa SMPN 2 Malang tetap tinggal dalam kelompok selama beberapa kali pertemuan.
Mereka diajarkan keterampilan khusus agar dapat bekerja sama dengan baik di dalam kelompoknya, seprti menjadi pendengan aktif, memberikan penjelasan kepada teman kelompok dengan baik, dan berdiskusi. Agar terlaksana dengan baik, siswa diberi lembar kegiatan yang berisi pertanyaan atau tugas yang direncanakan untuk diajarkan.

Pembelajaran kooperatif tidak berubah, terdapat beberapa variasi dan model kooperatif tersebut. Sedikitnya terdapat empat pendekaatn yang seharusnya merupakan bagian dari kumpulan strategi guru dalam menerapkan model pembelajaran kooperatif yaitu; STAD, Jigsaw, investigasi kelompok, dan pendekatan struktural yang melipiuti numbered head together (NHT).

\section{DAFTAR PUSTAKA}

Asan, A dan Haliloglu, Z. 2005. Implementing project Based Learning in Computer Classroom. Diakses 3 Februari 2014.

Beyer, B. K. 1991. Teaching Thinking Skill: A Handbook for Secondary School Teacher. Boston: Allyn and Bacon.

Ibrahim, M. dan Nur, M. 2000. Pengajaran Berdasarkan Masalah. Surabaya:University Press.

Ibrahim, M.Ramchmadiarti., F. Nur, M. 2000. Pembelajaran Kooperatif. Surabaya: Universitas Press.

Ismail. 2005. Model-model Pembelajaran. Jakarta: Dit. Pendidikan Lanjutan Pertama.

Johar,R.2006.Pengembangan Level Penalaran Proporsional Siswa SMP. Disertasi. Surabaya: Program Universitas Unesa.

Kardi, S.dan Nur, M. 2000. Pengajaran Langsung. Surabaya: Universitas Press. Masitah, dan Nur, M. 1998. Teori-teori perkembangan Sosialdan Perkembangan Moral. Surabaya: Program Pascasarjana IKIP Surabaya.

Peningkatan Mutu Prestasi Belajar Agama Hindu

Melalui Modelpembelajaran Kooperatif di SMP N 2 Malang 
Nur, M. 2001. Perkembangan Selama Anakanak dan Remaja. Surabaya: PSMS Program Pascasarjana Unesa.

Trianto. 2004. Mendesain Model Pembelajaran Inovatif, Progresif dan Kontektual. Jakarta: Prenada Media Group

Trianto. 2007. Mendesain Model Pembelajaran Terpadu (Integrate Curriculum Mudel) dalam Teori dan praktik. Jakarta: Prestasi Pusaka. 